\title{
Role of Formal and Informal Seed Sector in Augmenting Seed Replacement Rate in Raichur District of Karnataka, India
}

\author{
Umesh Hiremath*, Basave Gowda, B. S. Ganiger and G. Y. Lokesh \\ National Seed Project (Crops), Seed Unit, University of Agricultural Sciences, Raichur, India \\ *Corresponding author
}

\section{A B S T R A C T}

\begin{tabular}{|l|}
\hline K e y w o r d s \\
$\begin{array}{l}\text { Seed Sector, Seed } \\
\text { Replacement Rate, } \\
\text { informal seed sector }\end{array}$ \\
\hline Article Info \\
\hline $\begin{array}{l}\text { Accepted: } \\
\text { 18 May } 2020 \\
\text { Available Online: } \\
\text { 10 June } 2020\end{array}$ \\
\hline
\end{tabular}

\section{Introduction}

Seed is an essential input for crop production. Access of farmers to quality seed of superior varieties is key in increasing agricultural productivity and production. Use of quality seeds alone could increase productivity by 15 $20 \%$ indicate the critical role of seed in

\begin{abstract}
Meeting the ever increasing food demand with an alarming increased population is very challenging under climate changing scenario. This could be possible only through second green revolution or ever green revolution. For sustained agriculture production, a good quality seed is the most basic and essential input. Other inputs are contingent upon quality of seed for being optimally effective. The existing seed systems in India involve the formal seed sector, which is an official or private control of seed monitored through the various processes. The informal seed sector is simply the farmers themselves that provide each other and themselves with seed for sowing. Designing appropriate seed systems to meet the specific challenges demands clear identification of needs and strategies. It is very imperative to analyze the contribution of formal and informal seed sector in enhancing seed replacement rate. Hence, a survey based study has been conducted to discern the formal and informal seed sector contributions in seed supply in Raichur district of Karnataka. The formal seed sector is contributing $78 \%$ to total seed supply whereas, informal seed sector is contributing $22 \%$ to seed supply in the present study. Nearly $80 \%$ of the farmers are using quality seeds i.e. certified seed and truthfully labeled seed and remaining $20 \%$ farmers are using farm saved seeds. Significant variation has been observed with respect to quality of farmer saved seeds. More percentage of seedlings with primary infection was noticed in the abnormal seedlings category. 33\% of the farmer saved seeds were below the Indian Minimum Seed Certification Standards for physical purity. There is no significant change in crops was observed during last ten years. Majority of the farmers are using jute bags for storing their farm saved seeds.
\end{abstract}


the capacity to ensure food security by means of seed security. Over the last decade, global seed industry has tripled in size reaching USD 45 billion and is estimated to grow at same rate crossing USD 92 billion by 2020. USA, France, China, Brazil and India are top markets contributing to 66 per cent of total global market together. Indian seed industry is ranked at $5^{\text {th }}$ with overall size of USD 2.2 billion. Cotton is the largest segment in value terms with $\mathrm{Bt}$ cotton driving the growth. Indian seed industry estimated to grow at 1213 per cent crossing USD 3 billion mark by 2020 (Anon., 2015.)

In recent years, the situation is becoming alarming with the agricultural production reaching the plateau in most of the crops, shrinking natural resources and effect of changing climate. Climate change is very likely to affect the frequency and intensity of weather events such as floods and drought. It is emerging as a big threat to seed production by drastically reducing seed yield and increasing biotic and abiotic stress conditions during seed production. Along with this, shortage of labour and degradation of natural resources like land and irrigation are posing major bottlenecks in viable seed supply to farmers' doorstep. There are two types of seed system, i.e. informal and formal, prevalent in India. Formal seed system involves a chain of activities leading to clear products. Formal system generally consists of public sector research institutions, public and private sector agencies producing and marketing seeds, agencies responsible for seed certification and quality control. The guiding principles in the formal system are maintenance of varietal identity, genetic purity and production of seed with optimal physical, physiological and sanitary quality (Reddy et al., 2007). Formal seed systems are easier to characterize as they are deliberately constructed, involving a chain of activities leading to clear products certified seed of verified varieties (Louwaars
1994). The chain usually starts with plant breeding and selection, resulting in different varieties, hybrid parents including hybrids and materials leading to formal cultivar release and maintenance. The central premise of the formal system is that there is a clear distinction between seed and grain. This distinction is less clear in informal seed systems (Vilas et al., 2012)

In case of informal system, also known as village or farmer or local seed system, farmers themselves produce, disseminate and access seed directly from their own harvest, through exchange among friends, neighbours and relatives or through local grain markets. Encompassing a wide range of variations, local systems are characterized by their flexibility. The varieties disseminated may be landrace or mixed races and likely to be heterogeneous mixture of different varieties. In addition, the seed is of variable quality in terms of purity and physical and physiological parameters. While some farmers treat seed specially, there is not always a distinction between seed and grain (Vilas et al., 2012).

Hyderabad-Karnataka region comprising Bidar, Kalaburagi, Ballari, Yadgir, Koppal and Raichur, an agrarian area with an irrigation potentiality of 12 lakh hectares through Tungabhadra, Krishna, Karanja, Mullamari, Hirehalla, Bennethore and other irrigation projects, spanning a total geographic area of 44.96 lakh hectares accounting 33.60 per cent of the geographical area of the state, of which nearly 68 per cent is under cultivation and has a unique combination of medium (32.42\%) and large farmers $(36.69 \%)$ bestowed with rich natural resources especially for agricultural development. The prosperity and growth prospects of the rural economy as well as the region as a whole therefore, mainly depend on the growth of agriculture. The region is primarily a dry land region. The investment 
on the development of dry land agriculture has been marginal in the state as a result extreme backwardness in dry land farming dominates the region. Low annual rainfall, rugged terrain landscape, non-availability of long stretches of plain lands and hard clay soil texture incapable of retaining humus have crippled agricultural growth of the region.

To some extent seed requirement of farmers is met by farm saved seed, i.e. the farmers are using their own farm saved seed or seed distributed among them. Making the quality seed available at right time is greater challenge rather than production per se. Seed, being the principal input in determining productivity, seed replacement should be enhanced by using certified/quality seeds other than farm saved seed which is the major challenge to be dealt with. Even though there is slight progress recently, still a long way ahead in making the quality seed available at farmers' doorsteps, and for achieving target seed replacement rate. (Anon., 2013). Another prolonged problem of seed chain is Varietal Replacement Rate (VRR). Even though with more than 4500 varieties, which were notified and are available, indents for basic seed and its further multiplication is restricted to few varieties. It is very imperative to analyze the contribution of formal and informal seed sector in enhancing seed replacement rate in Hyderabad Karnataka. Hence, a survey based study has been conducted to discern the formal and informal seed sector contributions in seed supply in Raichur district of Karnataka.

\section{Materials and Methods}

\section{Data collection}

Survey was conducted in Raichur district of Karnataka state. From Raichur district, two blocks were selected randomly. From each selected block, five villages were selected through random sampling. The details are given in Table $\mathrm{A}$.

Data and information was collected through primary survey using structured questionnaire from each selected village wherein, ten farmers were selected through random sampling. Also, focus group interviews and key informant surveys were conducted. The total numbers of farmers were 100. The obtained data has been analyzed to discern the contribution of formal and informal seed sectors with respect to use of quality seed for crop production in the district. The samples of farm saved seed of each crop from every surveyed farmer was collected and tested for seed quality parameters viz., seed germination $(\%)$, physical purity (\%), seed moisture content (\%) and seed health as per ISTA rules.

\section{Results and Discussion}

A little-known, under-appreciated and persuasive concern in the global supply of crop seed is a dearth of systems providing seed for crops of import mainly to poor households in developing countries. Seed for such crops cannot be supplied economically by the formal and centralized seed sector. The resulting bottleneck in seed supply primarily affects self-pollinating crops, such as groundnut, chickpea, pigeon pea, black gram, and green gram which are served largely, if largely ineffectively, by local seed provision systems. Whereas the formal seed sector dominates supply of seed to farmers in industrialized countries, the informal sector is the main actor in developing countries. The formal seed sector of developing countries is controlled either by the state or private industry, which monitors the entire process of seed production starting from from breeding crop varieties to seed multiplication to seed processing to seed storage to ensure highquality. In the informal sector, on the other 
hand, seed may be manually cleaned but is otherwise mostly left untreated, which causes the resulting crop to the risk of seed-borne pests. Nearly all smallholder farmers endure to obtain seed from informal sector including their own seed. It is due to not only because of their inadequate access to the formal sector but also because the few cultivars and varieties available in the formal seed sector do not meet their prerequisites. The informal sector offers a dynamic and flexible supply of seed wanted by smallholder farmers. Furthermore, on-farm production of locally adapted landraces, cultivars and wild species aids farmers deal with precise tropical production complications caused by drought, flooding and other biotic and abiotic factors.

A survey based study has been taken in Raichur district of Karnataka state to analyze the role of formal and informal sectors with respect to the use of quality seed for crop production. In recent farmers have realized the use of quality seeds of improved varieties/hybrids with farmers adopting high value seeds replacing farm saved seeds contributing to overall increase of crop productivity and seed business value. Advances in seed technology have accelerated through marker-assisted breeding, genetic transformation and nanotechnology. Seed sector witnessed an exponential growth curve due to introduction of genetically modified hybrids/varieties. To witness this, in the present study, majority of the cotton farmers were cultivating bt-cotton hybrids and the only source of seed is private seed companies. Both public and private sector has played a vital role in laying a strong foundation to Indian seed industry, which is poised to become an important global player in the future. Indian industry has also been highly agile in adopting new varieties and hybrids which have delivered value. Future of agricultural production will largely depend upon development of improved varieties/hybrids in various crops. In this study, TS-3R redgram variety is popular and contributing its $74 \%$ share in redgram area cultivation and Department of Agriculture is major source of seed. This is an example of a significant contribution of formal seed sector especially public sector in India. Where as in sorghum, variety $M \quad 35-1$ has covered maximum area in two blocks. In paddy, BPT5204 variety is dominating one which is spreading through private seed source. In rabi crops, chickpea variety JG-11 has covered maximum area and Department of Agriculture is major source of seed to farmers.

Developing improved varieties and producing their seeds is a complex research-anddevelopment process. Seeds should be accessible in time, affordable and meet the true needs of farmers and markets. Seed systems are diverse but in few cases, most smallholder farmers get seeds from local, informal channels. Although, globally India seed industry ranked $5^{\text {th }}$ largest player with the robust growth, but domestically, only $24 \%$ sub-marginal and 29\% marginal farmers replace seed every year against $40 \%$ by large farmers. Overall, access to quality seed by small and marginal farmers is reported to be only $20 \%$ as reported by Roy (2015). The informal seed sector comprising mainly farmsaved seed (FSS), which accounts 65-70\% emphasizes the need to strengthen the seed system's resilience at local level (Anon., 2016a). On the basis of input survey conducted by the Agricultural Census Division of Department of Agricultural Cooperation and Farmers Welfare, Ministry of Agriculture and Farmers Welfare's, Government of India, out of a total of 138.11 million operational holdings, only $39.41 \%$ used certified seeds while $26.96 \%$ used seeds of notified varieties (Anon., 2016b).

On contrary, In the present study $35 \%$ farmers are using farm saved seeds for 
redgram sowing where as 59\% and $67 \%$ farmers are cultivating sorghum and foxtail millet by means of farm saved seeds (informal seed sector). Very few farmers are using farm saved seeds in crops like chickpea and paddy (6 and 11 per cent respectively) for sowing (Fig.1)

A robust seed system guarantees the sustainability of its agriculture to ensure that the products of modern plant breeding and local farmer ingenuity are widely available. Indian national seed system typically includes several components. Seed industry in India today has traversed its foundation stages and is currently at an inflection point to scale up into growth phase. While the learning curve has been steep at times, today we are the part of a vibrant seed industry with strong foundation to take-off into the growth phase.

The progress achieved since the new policy on seed development 1988 and national seed policy 2002 in terms of developing capacities by Indian Seed Industry with regard to research and development, product development, supply chain management and quality assurance has been phenomenal which has positioned India as the fifth largest seed industry globally (Anon., 2015). A commercial seed sector is necessary to ensure efficient seed supply. Both the public and private seed systems are relatively well developed in India. Hence, the opportunities of disseminating improved new varieties/hybrids to farmers are better.

Form the present study; it is eminent that formal seed sector viz. department of agriculture state agricultural universities, national seed corporation, state seed corporation, private seed shop have made significant impact with respect to seed supply. In redgram alone only $58 \%$ farmers are securing seeds from formal seed sector whereas remaining $42 \%$ farmers are depending on informal seed sector. While, in chickpea, $93 \%$ farmers are procuring seeds from formal seed sector and $7 \%$ farmers are solely depend on informal seed sector. In paddy, $89 \%$ farmers are acquiring seeds from formal seed sector with $11 \%$ farmers depend on informal seed sector. With respect to sorghum, $41 \%$ farmers are obtaining seeds from formal seed sector whereas, 59\% farmers are depending on informal seed sector viz. own saved seed and neighboring farmers in the villages. In case of cotton, $100 \%$ farmers are depending on formal sector i.e. private seed shop. While in chilli, all the farmers are solely depend on formal sector (Table 2).

Latest innovations in adaptive and participatory research go a long way in addressing the constraints related to farmers assessment to quality seeds. Seeds secure farmers tend to maintain their own varieties with limited influx of new varieties. In addition, awareness about variety selection is not always well developed in traditional farming communities. It may also reflect the fact that in traditional self-contained seed systems, the same genetic material may be easily available from neighbors, thus reducing the risk of seed procurement and accesses. (Asif A. Ali., 2016). In the present study also, the M-35-1 variety of sorghum is most popular among the farmers even though the variety is old but farmers preferred this variety owing to its quality and wider adaptability.

Private and public, informal and formal seed systems should cohabit to reach out to small farmers especially in the poor resources dry lands. A favorable seed policy initiatives has to aid the development of complementary seed channels both local, community based, and more formal seed organizations so that the seed industry is inclusive and responds to the needs of farmers. Improved varieties and 
hybrids of various crops are playing a critical role in enhancing the production and productivity especially in dry land conditions. In crops like redgram, variety TS-3R developed by public sector (UAS, Raichur) has made significant contribution with $74 \%$ area covered by this variety. Similarly, BPT5204 variety of paddy again developed by public sector is more popular with $42 \%$ contribution in area coverage among various paddy varieties. Likewise JG-11 variety of chickpea has covered $72 \%$ area under chickpea cultivation among various varieties (Table 3).
For the millions of smallholder dry land farmers who rely on rainfed farming, improved seeds are one of the most cost effective ways to enhance their yields, food security and livelihoods. Smallholder farmers have relatively low crop yields as they face multiple challenges from poor soils, numerous pests and plant diseases, drought and other climate shocks. A major issue is the poor quality of seeds which are saved by farmers.

Table.A

\begin{tabular}{|l|l|l|l|l|l|}
\hline District: Raichur & \multicolumn{5}{|c|}{ Villages } \\
\hline Block-I & Marchad & Askihal & Jakkaladinni & Athnoor & Idapanoor \\
\hline Block-II & Kallur & Kurdi & Madasirwar & Alabanoor & Huda \\
\hline
\end{tabular}

Table.1 Details on farmers cultivating different crops, varieties among surveyed farmers in Raichur district during 2018-19

\begin{tabular}{|c|c|c|c|c|c|c|c|c|}
\hline Crop & $\begin{array}{l}\text { Red } \\
\text { gram }\end{array}$ & Chickpea & Bajra & Paddy & Sorghum & $\begin{array}{l}\text { Foxtail } \\
\text { millet }\end{array}$ & Cotton & Chilli \\
\hline $\begin{array}{c}\text { No. of } \\
\text { farmers }\end{array}$ & 43 & 15 & 1 & 19 & 17 & 3 & 48 & 5 \\
\hline \multirow[t]{13}{*}{ Varieties } & $\begin{array}{l}\text { TS-3R: } \\
32\end{array}$ & JG-11: 11 & Local & $\begin{array}{c}\text { BPT- } \\
5204: 8\end{array}$ & M 35-1: 10 & $\begin{array}{c}\text { HMT } 100- \\
1: 1\end{array}$ & Bhagya:1 & Local:5 \\
\hline & Local: 11 & BGD-103: 3 & & IR-64: 1 & Mahalakshmi: 1 & Local: 2 & Challenger: 1 & \\
\hline & & GBM-2: 1 & & $\begin{array}{l}\text { Kaveri } \\
\text { sona: } 4\end{array}$ & Local: 6 & & Gemini:1 & \\
\hline & & & & Local: 1 & & & Jadoo:33 & \\
\hline & & & & $\begin{array}{c}\text { MTU 10- } \\
10: 2\end{array}$ & & & KCHB 335: 1 & \\
\hline & & & & $\begin{array}{c}\text { RNR } \\
15048: 3\end{array}$ & & & KICK-2: 1 & \\
\hline & & & & & & & Lakshmi:1 & \\
\hline & & & & & & & Mudra:1 & \\
\hline & & & & & & & Nidhi:1 & \\
\hline & & & & & & & Pallavi BG2: 2 & \\
\hline & & & & & & & Police: 2 & \\
\hline & & & & & & & $\begin{array}{c}\text { Rasi RCH } \\
\text { 659: } 1\end{array}$ & \\
\hline & & & & & & & SP 7517: 1 & \\
\hline
\end{tabular}


Table.2 Contribution (\%) of different formal and informal seed sector in seed supply in Raichur district during 2018

\begin{tabular}{|c|c|c|c|c|c|c|c|c|}
\hline \multirow[b]{2}{*}{ Source of seed } & \multicolumn{8}{|c|}{ Contribution in seed supply (\%) } \\
\hline & Redgram & Chickpea & Bajra & Paddy & Sorghum & $\begin{array}{c}\text { Foxtail } \\
\text { millet }\end{array}$ & Cotton & Chilli \\
\hline \multicolumn{9}{|c|}{ Formal seed sector } \\
\hline $\begin{array}{l}\text { Dept. of } \\
\text { Agriculture }\end{array}$ & 35 & 53 & - & 16 & - & - & - & - \\
\hline SAU's & - & 33 & - & - & - & 33 & & \\
\hline $\begin{array}{l}\text { National/State } \\
\text { Seed } \\
\text { Corporations }\end{array}$ & 9 & - & - & 21 & 18 & - & - & - \\
\hline $\begin{array}{l}\text { Private Seed } \\
\text { shop }\end{array}$ & 14 & 7 & 100 & 53 & 24 & - & 100 & 100 \\
\hline \multicolumn{9}{|c|}{ Informal seed sector } \\
\hline $\begin{array}{l}\text { Own saved } \\
\text { seed }\end{array}$ & 35 & 7 & - & - & 47 & 67 & - & - \\
\hline $\begin{array}{l}\text { Neighboring } \\
\text { farmers }\end{array}$ & 7 & - & - & 11 & 12 & - & - & - \\
\hline
\end{tabular}

Table.3 Contribution of varieties (\%) in area coverage of major crops in Raichur district during 2018

\begin{tabular}{|c|c|c|c|c|c|c|c|c|}
\hline $\begin{array}{l}\text { Crop / } \\
\text { Variety }\end{array}$ & $\begin{array}{c}\text { Redgram / } \\
\text { TS-3R }\end{array}$ & $\begin{array}{c}\text { Redgram / } \\
\text { Local }\end{array}$ & $\begin{array}{c}\text { Chickpea } \\
\text { /JG-11 }\end{array}$ & $\begin{array}{c}\text { Chickpea } \\
\text { / BGD- } \\
103\end{array}$ & $\begin{array}{c}\text { Paddy / } \\
\text { BPT- } \\
5204\end{array}$ & $\begin{array}{c}\text { Paddy } \\
/ \\
\text { Kaveri } \\
\text { sona }\end{array}$ & $\begin{array}{c}\text { Paddy } \\
/ \\
\text { MTU } \\
\mathbf{1 0 - 1 0}\end{array}$ & $\begin{array}{c}\text { Paddy } \\
/ \\
\text { RNR } \\
15048\end{array}$ \\
\hline $\begin{array}{c}\% \\
\text { contribution }\end{array}$ & 74 & 26 & 72 & 20 & 42 & 21 & 11 & 16 \\
\hline $\begin{array}{c}\text { Crop / } \\
\text { Variety }\end{array}$ & $\begin{array}{c}\text { Sorghum/ } \\
\text { M 35-1 }\end{array}$ & $\begin{array}{l}\text { Sorghum/ } \\
\text { Local }\end{array}$ & $\begin{array}{c}\text { Foxtail } \\
\text { millet/ } \\
\text { Local }\end{array}$ & $\begin{array}{l}\text { Cotton/ } \\
\text { Jadoo }\end{array}$ & $\begin{array}{l}\text { Chilli/ } \\
\text { Local }\end{array}$ & & & \\
\hline $\begin{array}{c}\% \\
\text { contribution }\end{array}$ & 59 & 35 & 67 & 69 & 100 & & & \\
\hline
\end{tabular}


Fig.1 Status on class of seeds being used by farmers in Raichur district during 2018

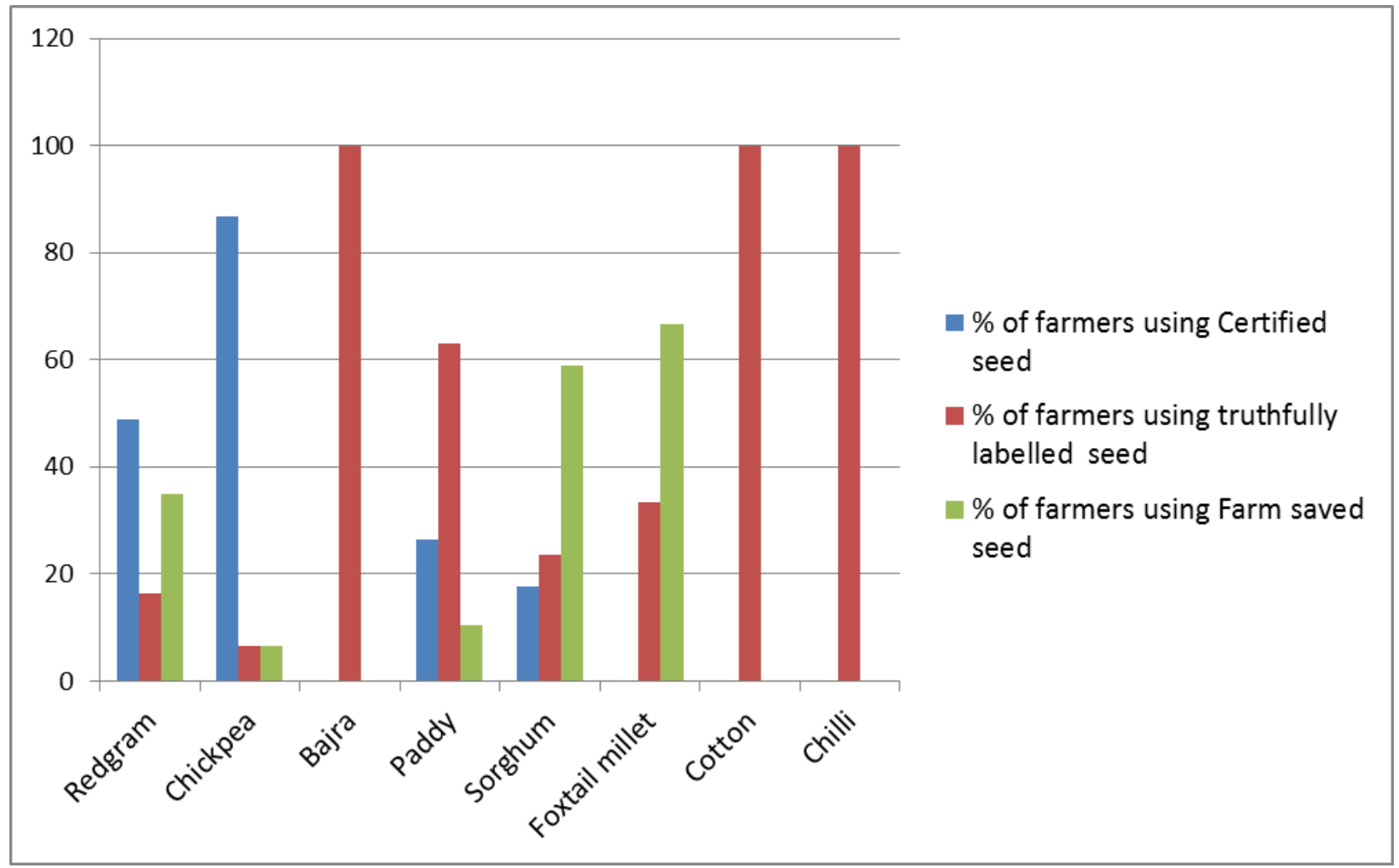

Significant variation has been observed with respect to quality of farmer saved seeds. More percentage of seedlings with primary infection was noticed in the abnormal seedlings category. $33 \%$ of the farmers saved seeds were below the Indian Minimum Seed Certification Standards for physical purity. If farmers can get the right improved seeds, associated with the right farming practices, the impact could be huge. There is no significant change in crops was observed during last ten years. Majority of the farmers are using jute bags for storing their farm saved seeds.

Public and private enterprises requires a set of steps to build and create access to new technologies and emerging markets. Critical is to select and aggregating appropriate complementary fragments of technologies developed in the public and private innovation system within country into an accessible package to adapt to meet specific needs. The farmers were also surveyed regarding crop change, storage practices and constraints related to use of quality seeds. In the present study, $98 \%$ farmers have not changed the crop during last 10 years and two percent farmers changed the crop during last 10 years due to less profit and introduced sorghum. Few (4) farmers expressed constraints like high cost of seed related to use of quality seeds. Some of the farmers expressed concern about non availability of subsidy to seeds purchased at State Agricultural Universities.

Safe seed storage must be practiced for the seeds produced until it is used for sowing and seed multiplication purposes. Since seed production is seasonal, and seeds need to be stored for some period of time raining from days to months depending on crops. Since seed is living entity, its quality is being 
affected by many biotic and abiotic factors during storage. Hence, safe seed storage must maintain seed quality and quantity. This means that seeds have to be protected from weather, molds and other microorganisms, moisture, destructively huge temperatures, insects, rodents, birds, objectionable odours and contamination, and from unauthorized distribution. Various methods are being followed by farmers for seed storage. In the present study $34 \%$ farmers are using jute bag for seed storage purpose.

In conclusion, quality seeds of high yielding varieties along with fertilizers and irrigation are the main drivers of green revolution in India and the seeds of these varieties are mainly supplied by the formal seed sector. It is observed from the study that majority of the cotton farmers were cultivating bt-cotton hybrids and the only source of seed is formal sector i.e. private seed companies. With respect to redgram, $74 \%$ area is covered by TS-3R variety and formal seed sector (Department of Agriculture) is major source of seed. Where as in sorghum, variety M35-1 has covered maximum area in two blocks. In paddy, BPT-5204 variety is dominating one covering $42 \%$ area which is spreading through formal sector i.e. private seed source. In rabi crops, JG-11 variety of chickpea has covered $72 \%$ area under chickpea cultivation among various varieties and formal sector in particular Department of Agriculture is major source of seed to farmers. The formal seed sector is contributing $78 \%$ to total seed supply whereas, informal seed sector is contributing $22 \%$ to seed supply in the present study. Nearly $80 \%$ of the farmers are using quality seeds i.e. certified seed and truthfully labeled seed and remaining 20\% farmers are using farm saved seeds. Significant variation has been observed with respect to quality of farmer saved seeds. More percentage of seedlings with primary infection was noticed in the abnormal seedlings category. $33 \%$ of the farmer saved seeds were below the Indian Minimum Seed Certification Standards for physical purity. There is no significant change in crops was observed during last ten years. Majority of the farmers are using jute bags for storing their farm saved seeds.

\section{References}

Anon., 2013. Vision 2050, Directorate of Seed Research. Pp. 1-23

Anon., 2015. India: Seed hub for Asia and Africa- A Knowledge report for enhancing seed exports from India. Sathguru Management Consultants. Pp 1-71.

Anon., 2016. State of Indian Agriculture 2015-16. Department of Agriculture, Cooperation \& Farmers Welfare, Directorate of Economics and Statistics, Ministry of Agriculture \& Farmers Welfare, New Delhi, Govt. of India. Pp 280.

Anon., 2016b. All India Report on Input Survey 2011-12, Agriculture Census Division, DAC \& FW , Ministry of Agriculture and Farmers Welfare, New Delhi. Pp 521.

Asif A. Ali., 2016. Role of seed and its technological innovations in Indian agricultural sector. Biosci. Biotech. Res. Comm. 9(4): 621-624.

Louwaars, N., 1994. Seed supply systems in the tropics: International course on seed production and seed technology. Wageningen, The Netherlands: International Agricultural Center.

Reddy Ch Ravinder., V A Tonapi., P G Bezkorowajnyj., S S Navi and $\mathrm{N}$ Seetharama., 2007. Seed system innovations in the semi-arid tropics of Andhra Pradesh, International Livestock Research Institute (ILRI), ICRISAT, Patancheru, Andhra Pradesh, India. Pp 224.

Roy TN., 2015. Review on access of small 
and marginal farmers to improved seeds in India. Economic Affairs. 60(4):713-719.

Vilas A Tonapi., Ch Ravinder Reddy., B S Tomar., Sanjay Singh., Sushil Pandey., S Rajendra Prasad., S Natarajan and Sandeep K. Lal., 2012.
Strategies to build viable community seed systems in dry land ecosystems for sustainable seed and food security in India. Directorate of Seed Research, Post Bag No. 11, Village: Kushmaur, PO: Kaithauli, Mau 275101 (UP), India. Pp 43.

\section{How to cite this article:}

Umesh Hiremath, Basave Gowda, B. S. Ganiger and Lokesh, G. Y. 2020. Role of Formal and Informal Seed Sector in Augmenting Seed Replacement Rate in Raichur District of Karnataka, India. Int.J.Curr.Microbiol.App.Sci. 9(06): 1852-1861.

doi: https://doi.org/10.20546/ijcmas.2020.906.230 